\title{
What is critical thinking? A longitudinal study with teacher candidates
}

\author{
Serap Yılmaz Özelçi, Gürbüz Çalışkan \\ Eregli Faculty of Education, Necmettin Erbakan University, Turkey
}

\begin{abstract}
Article Info
Article history:

Received Jul 18, 2019

Revised Aug 19, 2019

Accepted Aug 30, 2019

\section{Keywords:}

Critical thinking

Longitudinal study

Teacher candidates

ABSTRACT

Critical thinking skills that enhance the ability of individuals to understand and make sense of the world and events and situations around them are one of the foremost research areas in the educational system of various countries. As a critical thinking individual, decisions made by the teacher in his/her class, the activities he/she has performed and the explicit and implicit messages given by him/her to the class are clearly observed by the students. It is believed that the situation of teachers' having critical thinking skills and critical thinking personality effects on students' perceptions and achievements about critical thinking. In this context, the aim of the research is to determine the perceptions of the teacher candidates about critical thinking and to observe the changes in these perceptions over time. Interviews were held with 11 prospective teachers for two times for 4 years and their thoughts on critical thinking were examined. According to the findings obtained, the thoughts of the teacher candidates regarding the critical thinking do not change over time but they are not seen enough. Teacher candidates make decisions with emotional references and they are reluctant to inquire and research.
\end{abstract}

Copyright $\odot 2019$ Institute of Advanced Engineering and Science. All rights reserved.

\section{Corresponding Author:}

Serap Yılmaz Özelçi,

Curriculum and Intruction Department, Eregli Faculty of Education,

Necmettin Erbakan University,

Nişantaşı Mah., Dr. Mehmet Hulusi Baybal Cd. No. 12, 42060 Selçuklu/Konya, Turkey.

Email: syozelci@eerbakan.edu.tr

\section{INTRODUCTION}

The most important way to gain democratic culture and thinking action for individuals is modern education. Modern education aims to raise individuals who can think, criticise, interpret, test, and question [1-3]. In this context, thinking and being able to think have an important place in modern education. Knowing instinct and curious impulse which are at the core of thinking have the power of change and development as the individual's evolutionary, hereditary development and change [4]. Thinking is defined as the ability to make comparisons, analyze, synthesize, understand connections and forms [5]. In other words, thinking is the regulation and evaluation of the conceptualizing, practicing, analyzing and evaluating the information obtained by thinking, observation, experience, intuition, reasoning and the other ways [6]. It is the job of linking information [7]; is the way of understanding/interpreting the world [1]. According to Cüceloğlu [8] thinking is an effective and goal- oriented cognitive process that involves many processes in order to understand the present situation. One of the most important functions of language is to provide thinking, especially thinking critically $[9,10]$ and becoming competent in critical thinking skills through language, indivudials have the ability to read, understand and express their thoughts clearly and apprehensibly [11]. Critical thinking, based on certain criteria and methods such as clarity, consistency, reasoning, skepticism and correct reasoning on any subject, case and idea; thanks to both the problem-solving and the problem-seeing capacity, which recognizes inadequate ways of thinking, exhibits a deeper tendency 
of thinking, attitude and skill based on research attaching importance to evidence and conclusions, thus aiming at achieving consistent, reasonable conclusions and judgements, not merely any of conclusions, is a thinking process which is open to change and self-correcting by constantly controlling his own. Critical thinking is collecting evidence and supporting them with evidence before accepting anything [12]. Sternberg [13] argues that critical thinking is the mental processes, strategies and presentations that people use to solve problems. According to Kazanc1 [14], critical thinking is the attitude and skills used in the processes of judging and evaluating the consistency and validity of the problem with different criteria. Facione [15] has divided critical thinking skills into sub-dimensions of interpretation, inference, explanation, analysis, evaluation and self-regulation. Cüceloğlu [8] defines critical thinking as an active and organized mental process aimed at understanding ourselves and the events in our circle by applying what we learn, in the consciousness of our own thought processes, taking into consideration the thought processes of others. According to Üstündağ [16], it is a process involving intellectual skepticism and being skeptical and information gathering in this direction. In addition, critical thinking is a mental and emotional process involving scientific thinking, evaluation and improvement based on new situations and criteria, the effective and impartial disciplinary application of thinking processes that require examine and question sophisticatedly in the process of knowledge acquisition [17, 18]. According to Munzur [19]; critical thinking is seriously asking for meaning, evaluating knowledge and making analysis. Critical thinking skill that enhance the ability of individuals to interpret and understand the events and circumstances of the world and their circles are one of the areas of research highlighted in the education system of various countries [20, 21]. Some educational psychologists $[22,23]$ state that the concept of critical thinking is an important element in 21 st century education. Huitt [23], in the information age, thinks that thinking plays an important role in a person's success. For this reason, all societies , especially through educational systems, are trying to raise individuals who are inquisitor, questioner, critical thinker, sensitive, participating, have problem-solving skills and knowledge and able to communicate effectively [24-27]. In our everyday life, the concept of "criticism" is frequently used, and it is discussed how critical thinking, which is one of the higher-order thinking skills, can be transferred to this life. There are also debates about how this is taking place through educational efforts [28]. Critical thinking is often understood as a set of concrete, transferable and measurable skills and competences [29]. Teaching critical thinking formally, this is regarded as a skill that can be taught and developed; actualize through the learning outcomes in the curriculum. In this process, the perception and competences of the teachers about the subject are as important as the curriculum applied. Because, critical thinking skill is a skill that can be taught to individuals of all ages, and teachers are the most important factors in teaching this skill [25]. In order to be able to raise individuals who can think critically, it is firstly necessary for teachers to acquire critical thinking, to acquire the ability to use it throughout life, and to be trained in this way. Because a qualified teacher, besides having the knowledge and skills required in the subject area and the pedagogical competencies of the profession, should have the skills thinking, questioning and criticizing, developing and being open to new ideas [30]. From this point of view, the development of critical thinking skills of prospective teachers will provide them with the opportunity to explore and develop their own potential by influencing their intellectual development in a positive way [31]. As the teachers are the people directly responsible for this process, the most important task falls to the teachers. Decisions made by the teacher, as a critical thinking individual, in his / her class and the activities he / she has performed, the explicit and implicit messages given by him / her are carefully observed by the students. It is believed that the teachers' -as a role model in the classrooms- critical thinking skills and state of having the characteristics of a critical thinking individual have influence on the students' perception of critical thinking and critical thinking achievements. In this regard, opinions of teacher training institutions and the students there about critical thinking and teaching critical thinking gain importance. How the prospective teachers define critical thinking, the examples of behavior that teacher candidates regard as a sign of critical thinking in their everyday life and academic life, how they perceive themselves in this context, their thoughts about taking advantage of critical thinking skills in their professional and personal lives are all important issues. On the other hand, it is important to emphasize whether the pre-service training process has any effect on these considerations. The probable / expected contribution of educational experiences from the first grade to the fourth grade to the teacher candidates' world of thought should be questioned. Competence in the critical thinking skills of Turkish and Primary Mathematics teacher candidates should be prioritized in achieving these skills in the students and especially in reaching the modern educational goals. Because learning and teaching environments in Turkish and mathematics teaching should be organized in such a way as to encourage the students to develop their critical and creative thinking skills, to encourage their originality, encourage them to learn and to express their thoughts [24]. For these reasons the main aim of the research was to determine the Turkish and Primary Mathematics teacher candidates' critical thinking skills and their thoughts about how to gain this skill to the students in their professional lives by referring to their own opinions. 
The main aim of this research is to determine the thoughts of the prospective teacher candidates about their critical thinking skills by referring to their own opinions and to examine whether these considerations are influenced by the period of undergraduate education.

\section{RESEARCH METHOD}

As the teacher candidates' opinions were handled in accordance with their declarations, the research designed in qualitative research design. Interview technique was used to gather data.

Students who are studying in the undergraduate programs of Turkish Teaching and Primary Mathematics Teaching at Necmettin Erbakan University Ereğli Education Faculty constitute the research population. The sample is based on convenience sampling and volunteerism. The research aims and duration were explained and interviews were held with the students who wanted to participate in the study. Since the study was designed as a longitudinal study, the sample was selected once in the spring semester of 2013-2014 academic year on the basis of volunteerism among the first year students. The first interviews were conducted by the second researcher with 13 teacher candidates. The second interviews were repeated by the first researcher in the fall semester of 2016-2017 academic year. Due to the data losses experienced during the fall semester of the 2016-2017 academic year, the initial interview data of these participants were also not included in the analysis. In the end, 11 teacher candidates (Turkish Teaching 3F, 3M; Primary Mathematics Teaching $2 \mathrm{~F}, 4 \mathrm{M}$ ) formed the study group of the research. The average age of participants is 22.3. All participants maintained the vast majority of their lives in the city center. Information related to study group is given in the Table 1.

Table 1. Study group

\begin{tabular}{|c|c|c|c|c|c|}
\hline Participant & Departmant & G & Age & $\begin{array}{l}\text { 2013-2014 } \\
\text { I.Interview }\end{array}$ & $\begin{array}{c}\text { 2016-2017 } \\
\text { II. Interview }\end{array}$ \\
\hline $\mathrm{TC}_{1}$ & Turkish Teaching & $\mathrm{F}$ & 24 & + & + \\
\hline $\mathrm{TC}_{2}$ & Turkish Teaching & $\mathrm{F}$ & 20 & + & + \\
\hline $\mathrm{TC}_{3}$ & Turkish Teaching & M & 23 & + & + \\
\hline $\mathrm{TC}_{4}$ & Turkish Teaching & M & 23 & + & + \\
\hline $\mathrm{TC}_{5}$ & Turkish Teaching & $\mathrm{F}$ & 23 & + & + \\
\hline $\mathrm{TC}_{12}$ & Turkish Teaching & M & 23 & & (do not want to participate) \\
\hline $\mathrm{TC}_{6}$ & Primary Mat. Teaching & $\mathrm{F}$ & 22 & (gone with & undergraduate transfer,reached via email) \\
\hline $\mathrm{TC}_{7}$ & Primary Mat. Teaching & M & 22 & + & + \\
\hline $\mathrm{TC}_{8}$ & Primary Mat. Teaching & $\mathrm{F}$ & 21 & + & + \\
\hline $\mathrm{TC}_{9}$ & Primary Mat. Teaching & M & 23 & + & + \\
\hline $\mathrm{TC}_{10}$ & Primary Mat. Teaching & M & 2 & + & + \\
\hline $\mathrm{TC}_{11}$ & Primary Mat. Teaching & M & 2 & + & + \\
\hline $\mathrm{TC}_{13}$ & Primary Mat. Teaching & $\mathrm{F}$ & 2 & (gone with ur & ndergraduate transfer, could not be reached) \\
\hline
\end{tabular}

As a data collection tool in the survey, "interview form for critical thinking" prepared by Y1lmaz Özelçi [32] was used. The semi-structured form consisting of 9 questions and descriptive questions was tested with interviews with 2 teacher candidates outside the sample. A tape recorder was used during the interviews in accordance with the permission received from the participants. Each interview lasted 20-25 minutes on average. The obtained data were solved with inductive and deductive understanding in terms of themes (self-recognition, decision-making, generating alternatives, objectivity and evidence seeking) that formed the interview questions and stated in the aims of the research. The coefficient of agreement between the coders was calculated and found to be acceptable. Findings, accompanied by individual quotes were presented according to the order of the questions in the interview form. In the quotations, teacher candidates are mentioned according to the numbers in the raw data in the form of TCx.

\section{RESULTS AND DISCUSSION}

\subsection{Teacher candidates' views on self-recognition status in first and fourth grades}

First of all, Turkish teacher candidates were asked to "introduce themselves in three words and explain why they chose these words." All of the teacher candidates answered the question without hesitation. They have included in their descriptions personal thoughts or features that their friends / circles ascribe them. While a teacher candidate chooses to identify him/herself in terms of living conditions and surrounding contexts, all other participants are successful and confident in recognizing themselves. In 2017, the fourthyear teacher candidates were asked to identify themselves again. Teacher candidates frequently mentioned the examples and the experimentations they have gained from past experiences when describing themselves. 
In parallel with their statements in the first grade, they tried to define themselves through their past experiences, personal opinions, or features that their circle ascribes them. Among the expressions of the teacher candidates, the most remarkable is that the three teacher candidates ( $2 \mathrm{~F}, 1 \mathrm{M})$ express themselves using the same expressions used in the first grade. In particular, TC1 directly identifies herself through the same example. Examples of the statements in the first and fourth grade of TC1 (F) are given below, respectively.

TC1 (F): Emotional, overemotional, fidgety, and loving to laugh. My emotional being is maybe because of the horoscope. I'm a Pisces. Everyone says I'm emotional. Maybe that's why I am. But I have sensuality. Even in the slightest case my eyes brim with tears. I am a person who loves laughing. I smile immediately in the slightest thing. Even if nobody laughs, I still laugh at the most disgusting humor. Sometimes people find me odd. I like to be active when it comes to being fidgety (2014) TC1 (F): cheerful, emotional, and chatty. My circle says I'm like that. I think I'm like that, too. Even the simplest jokes I laugh. I even smile at people I do not know. I like to smile. I'm a Pisces. Sensuality is also from characteristics of my horoscope. I agree with that. If a movie or an advertisement has any sensuality, my eyes brim with tears immediately (2017).

Secondly, primary school mathematics teacher candidates were asked to "identify themselves in three words and explain why they chose these words" during the spring semester of the 2013-2014 academic year. In the definitions of the five teacher candidates, they expressed opinions about themselves with their personal thoughts as well as the words that they thought their friends/circles associated them. Four teacher candidates gave examples from their lives while describing themselves. Fourth grade primary school mathematics teacher candidates were asked again the words they would choose and the reasons of choosing that words when they wanted to introduce themselves to someone he met for the first time. Teacher candidates mentioned the examples and the experimentations they have gained from past experiences when describing themselves. While teacher candidates in the first grade were predominantly defined both in terms of their personal thoughts and those of the people around them, in the fourth grade this situation has changed. They have identified themselves in the fourth grade, on the basis of their own viewpoints. Among the expressions of the teacher candidates, the most remarkable is that the three teacher candidates (TC6, F; TC8, F; TC10, M) express themselves using the same expressions used in the first grade. Particularly, TC8 (F) and TC $10(\mathrm{M})$ define themselves directly on the same sample. Examples from the statements from the first and fourth grades of TC8 (F) and TC $10(\mathrm{M})$ are given below respectively:

TC8 (F): I am a person who is determined, who loves to live life to the fullest, loves to live life to the fullest deeply both when I am sad and happy. Third is the stubborn, we can say. This is both my thoughts and the ones that ascribe me. For example, if I feel sorry for an event, I can wear too much myself out. I feel very sorry. This does not make much difference; it could be a very trivial event or an important event. This is same when I feel happy. I can be happy for something tiny in the same way as a big thing. Determination; for example, I like to go over something I do not like or cannot do. I said I was stubborn, but this means if I wanted something, I would insist on doing it. (2014) TC8 (F): Determined, ambitious and stressed. I am determined because I am very persistent in my decisions and I do not give up my decisions easily. For example, I decided to become a teacher in primary school 5th grade, and this decision continued until the last grade of high school, and now I am a teacher candidate. I am ambitious, because I do not give up working and trying to do it for the second time when I fail. I recover my frustrations, but I keep working again. I am stressed and I reflect this on every work I do in every area of my life. For example, even when doing a simple homework I feel too much stress and I cannot relax without completing homework (2017).

TC10 (F): Pessimist, idle and lazy. I don't want to do anything. Especially at school. I cannot take a positive look at an incident. It does not happen willingly; it happens automatically. My circle says the same. (2014) TC10 (F): Pessimist, idle and lazy. I think negatively against any kind of thing, I cannot think positively. I'm not determined to do a task; I do not want to do it. I do not like to work any matter. I'm reluctant (2017).

When examining the expressions of primary mathematics teacher candidates at first grade, it was determined that especially the male teacher candidates (TC7, TC9, TC10, TC11) had a negative evaluation such as "pessimistic", "lazy", "idle", "obsessed" and "thoughtful". It was observed that the female teacher candidates (TC6, TC8) did not include negative descriptions for themselves much in the first grade. When examining the expressions in the fourth grade of the teacher candidates, it is not seen that the majority of the teacher candidates, except one teacher candidate (TC10, M) have a negative evaluation of their own characteristics. The situation is similar for Turkish teacher candidates. When teacher candidates' statements either in the first grade or in the fourth grade are examined, it is unlikely that none of them make negative evaluations about their qualifications or dissatisfied with any situation. 


\subsection{Teacher candidates' views on decision making in the first and fourth grades}

Questions were asked to teacher candidates to understand their decision-making processes. They were asked to explain by examples from everyday life decisions to critical decisions how they follow making decisions processes. Teacher candidates' answers are summarized under the headings of information gathering process, decision making criteria and situation of making wrong decision. All of the Turkish teacher candidates stated that they had lived without planning and that they decided instantly according to what happened during the day. Only one teacher candidate said that she usually postponed the decision making by saying, TC2 (F), "not last much longer, but I still think and wait till the last day. I cannot decide immediately, I have to think in every aspect and generally it remains to last". Two teacher candidates (TC4) identify themselves as "indecisive". Teacher candidates' thoughts on the information gathering process are similar. TC1 also stated that he is in charge of his decision-making process in addition to his uncertainty, saying that "I decide difficultly. But I decide absolutely; I do not go out without a decision. In the final I decide by myself. Namely I decide myself. Sometimes it happens when I regret, but even then I do not ask one. I decide my decision". Turkish teacher candidates find it necessary to gather information when deciding. The primary source of information for all participants is family. Other sources for participants who indicated that they get initially their parents' opinion on the topic are experienced people, trusted / loved friends. Teacher candidates, on the other hand, mentioned many different criteria when they gave their decisions. The criterion such as liking, suitability to family structure, benefit / damage provided by the result, prices affect the decisions of the teacher candidates.

TC2 (F): generally in the direction of my father; I think it is good for me too if something is good for him. I usually consult my father. The general stance of my father; he allows me for lots of thing, sometimes he says no when I never expect. If I have friends who can think well, I consult them. Then I have a guiding instructor, I ask him. TC4 (M): First, I consider the extent to which the event will affect my family, I think of my family. I look at the influence on the people around me; maybe the society I live in requires this. When I do something important, I think family oriented as it is not just for me but for my family too. I mean, it can be difficult. It is very difficult if the thing is contrary to my character and my family. I have a lot of contradictions in me, and I make the decision that influences my family at least.

In general, it has been seen that the Turkish teacher candidates care the thinking of others (family/friends) and abide by this criterion during the decision-making process. Another question directed at the participants is what they experience and what they feel when their decision is wrong. While all of the Turkish teacher candidates stated that they would be sorry in such a situation, no teacher candidate mentioned "remorse". The two teacher candidates (TC2, TC5) stated that besides their sadness they would try to correct the situation they are in even if they were not to return from their decisions; the other three teacher candidates said that even if they feel sorry, this sadness would not make change their decision. This situation is explained by the teacher candidates TC3 (M) "I do not regret it because I decide, I made it myself with my own thoughts. The outcome may be bad; this decision came out of me. I go on even if there is an error, because I made it. I do not return because of loss." by TC5 (M) "I feel sad actually. I did not want to take the incident again. Even if it is wrong, I bear it. I have to bear it, do not return to beginning." In the expressions of the Turkish teacher candidates, one of the questions that most differences are observed over the years is the questions about "decision making". In 2014 all participants expressed that they live without planning, but in 2017 they separated their expressions into "simple decisions" and "important decisions"; they have emphasized that in important decisions, the decision-making periods are "long" and the thinking processes are "detailed". The two teacher candidates (TC2, TC5) explain the decision-making process in the same way that they use at the first grade. The expressions of TC2 are:

... I try to decide what is best... 2014

...the result is more important to me. I try to make a decision according to the result whether

it will harm or make me happy in the end. Rather than the difficulties in the process, the results affect me much more...2017

In 2017, suitability for personality, advantages / personal benefit, level of expectation satisfaction, risk of decision, and environmental factors are added to the criteria that participants used in decision making in 2014. When asked about their feelings and actions when they are wrong, their answers were partly different from the answers they gave in 2014. While none of the participants who previously stated that a wrong decision would upset them, but did not speak of regret; when they came to the fourth grade, three teacher candidates expressed their remorse. TC1 (F) stated that he is postponing further to compensate for an existing regret, and TC5 (F) has expressed his regret as an experience. TC3 (M) stated that he would not change his decision even if he regrets saying "I feel regret. I maintain my decision eve if it is wrong. If I started something, I go on even if it is wrong".

After the Turkish teacher candidates, the questions under the heading "decision making" were directed to the primary school mathematics teacher candidates respectively. Four of the teacher candidates 
stated that they had lived without planning and made an instant decision according to what happened during the day. The teacher candidates mentioned that they decided instantly by saying "I do not think too much. I let it go. I do not stay in quandary. Whatever I feel in my heart and I relieved with, I immediately decide. Someone called me, I accept it immediately. If there are two alternatives, I do my best and I bring the two together, but I will not give up any of them." (TC6 (F)) and "I make an instant decision. I act without thinking. When deciding to what I wear, I wear what I find in the wardrobe. It's not about befit well to me or not, they are not all good anyway. I have not have brand obsession until today. I buy after I decide it."(TC7, M). TC11 (M) has also explained the decision-making process by saying "I cannot say that I made my university choice myself anyway. We went to a private teaching course and I told them what I had in my mind. A teacher from private teaching course told me to think about being Mathematics teacher. Afterwards, I find it logical somehow and I chose Mathematics teaching. It's hard for me to make decisions. I cannot be quite sure. I do not know anymore, mystery. I cannot be sure". TC8 (F) exemplified that she does not make a sudden decision by saying "I have research habit. It happened recently too. Someone shared one saying on a social network site on the internet. A saying I've heard before. But I had heard that it belongs to someone else. I searched on the internet. I saw that the writing on the site was correct, and what I knew was wrong. Then I did not get convinced and I sent a message to one of the instructors. Then we looked at the books with him- so and so. If I am obsessed with something, I do research." All primary school mathematics teacher candidates find it necessary to gather information in the decision-making process and their primary source of information is family. Other sources for participants who indicated that they initially get the opinion from their parents on the topic are experienced people, trusted/loved friends. Teacher candidates, on the other hand, mentioned about many different criteria when they make their decisions. The criterions such as liking, suitability to family structure, benefit/damage provided by the result, price affect the decisions of the teacher candidates.

TC8 (F): first of all I think very much. If a limited time is given to me, I do not ever leave to decide for the last minute. I definitely make time for myself for the possibility of changing my decision. I do not leave for the last minute. For example, if I have 18 days, I will think until the 15 th day. Seriously. My criteria are as follows; how can this decision affect me, how can it affect my family can I be happy with the decision I made, or not, then; I consider most whether I want or not. Of course my mother's and my father's wishes and desires are also important. I get their opinions. Again, I get the opinions of my friends whom I trust in sincerity and I decide accordingly.

Another question directed at the participants is what they experience and how they feel when the decision is wrong. All teacher candidates have stated that they will be sorry for such a situation, but no teacher candidates outside of the two teacher candidates (TC8 F, TC11 M) have mentioned "remorse". TC11 (M): I regret, in the simplest term. I try to fix it. A fault confessed is half redressed.

In 2017, the decision-"making" titled questions were redirected to primary school mathematics teacher candidates again. In 2014, four participants said that they had lived without planning and made an instant decision, but in 2017 the number of participants has fallen to three. In general, the criteria that the teacher candidates stated to use to decide have not changed over time. The following are the thoughts of TC9 (M) relating to the matter:

TC9 (M): My decisions. In fact, most of the time, I avoid from making sudden decisions. But when I was angry I decided a lot and sometimes I cannot get ahead of it. Because when I'm angry I am blind to everything. Of course it is not about violence or anything like that. (2014) TC9 (M): I usually make a quick decision, I get a quick proceed. My family usually supports my ideas. Especially my brothers tell me that they are behind me whatever I decide (2017).

When asked about the feelings and actions of participants in the situaiton of making wrong decisions, their responses were partly different from the answers they gave in 2014. Two of the participants who stated that a wrong decision would upset them mentioned about remorse before, but when they came to the fourth grade, only one teacher candidate (TC10 M) expressed that he feels regretful. TC8 (F) and TC11 (M) who said that they would regret their mistakes in the first grade said that they would no longer feel regret in such a situation in the fourth grade.

\subsection{Teacher candidates' views on generating alternatives in the first and fourth grades}

The views of the teacher candidates about being open to alternatives and the inclination to generate alternatives when necessary are also covered within the scope of the research. Findings related to the views of Turkish teacher and primary school mathematics teacher candidates were given respectively. A teacher candidate (TC1) from the Turkish teacher candidates stated that if the data in her hand did not provide a solution, she would seek an alternative and a teacher candidate (TC4) would decide to seek an alternative according to the importance of the problem; while the other three teacher candidates indicated that they considered the alternative important when deciding. Example of teacher candidates' views: TC3 (M): I do not 
think of one solution, I find solutions. I specify the stages of these; plan A, plan B in order. I turn the solution in my mind and I use an alternative.

When they are in fourth grade, the opinions of the Turkish teacher candidates differed. It has been observed that previously, two teacher candidates who were "open" to generate alternatives saw this as "unnecessary / confusing" in the last grade; and a teacher candidate who has previously been "closed" to seek an alternative sees this as "necessary" in the last grade. TC1 (F): There may be more than one solution to a problem. I will apply the one which is the most reasonable and the most economical. If there is only one solution, I will use it as well. If a solution is given to me and if it makes sense I will enforce it, but if it is unreasonable, of course I think, and seek new alternatives. When the opinions of primary school mathematics teacher candidates regarding the subject in the first class are examined; two of the prospective teachers (TC6, F; TC7, M) stated that they would not seek another solution if there was a single solution. Four other teacher candidates expressed that they are open to generate alternatives. A teacher candidate (TC11, M) stressed that time is decisive in the point of generating alternatives by saying “...Depends on time. For example, I look at the time when solving Turkish on the exam, and if I have 10 minutes, I pass by marking the question directly. If I have time, I read." Examples of teacher candidates' opinions on the topic are as follows:

TC8 (F): Much more alternatives may be better for me. I choose multiple alternatives. For example, I went home, my mother has gone. First, I call my mother. If she doesn't answer, I call my father. I f he doesn't answer too, I go to my grandma. I f she is absent, I go to my aunt. I fend for myself somehow. I read anyway all the options in examinations. Even in some tests I know obviously that the right option is "a", and actually I do not even need to look at the others, but I still read them. Sometimes I do it, even if it's a waste of time. Thinking that, I may change my mind.

When looked at the views in the fourth grade, unlike the Turkish teacher candidates, there was no difference in the views of the primary school mathematics teacher candidates. While the thoughts of the five participants remained the same, a prospective teacher who previously indicated that she was "close" to generate alternatives, stated that she saw it as "necessary" in her final grade. Some examples from teacher candidates' expressions are:

TC6 (F): I search for more effective solutions until I am certain that the solution is right for me.

TC7 (M): It would be enough for me, too. I do not generate alternatives, I use the ready one.

\subsection{Teacher candidates' views on seeking evidence in the first and fourth grades}

Turkish and primary school mathematics teacher candidates were asked in which situations they believe the truth or validity of an idea, in which situations they changed their decisions and how they evaluate advertising and propaganda. When the opinions of Turkish teacher candidates regarding the criterions of the accuracy of knowledge are examined; they were found to decide with emotional references. Teacher candidates believe in the validity of knowledge according to the plausibility of the discourse or the state of being persuaded. In dual conversations, the speaker's credibility seems to be enough to believe and persuade. Family elders, person's style and attitude, people's general perception / circle and age are the most basic criteria affecting the decisions of teacher candidates. Two teacher candidates summarized their thoughts on this subject as:

TC5 (F): There are moments I cannot decide. I talk to the others, I think same as the people I trust. I ask my family. Of course they can also make the wrong decision, but when everyone says "yes" in a topic, it is very low to be wrong. I do not know. I try to learn by asking a friend. Depends on her personality...

The thoughts of the Turkish teacher candidates regarding the source of information are remarkable. The main sources for participants to "research" are internet, close / trusted friends and family. In the research process, it was observed that the candidates' "readings" were "read from the internet" and when they expressed "research" they mean "establishing a communication chain with their friends via social media or sms". On the other hand, again in the above example (TC5), "... when everyone says "yes" in a topic, it is very low to be wrong" is a devastating finding of research. When the same participant was asked "You read a news on a newspaper and find it suspicious, what do you do?" she replied "neither I like to investigate, nor am I curious. I read and it finishes there; I do not mull over." When Turkish teacher candidates asked about the possibility of changing their decision, four teacher candidates stated that their decisions change and they thought it is natural, but one of the teacher candidate (TC3, M) indicated that he changes his decisions, but he is not pleased with this situation. Examples from the teacher candidate's expression are:

TC3 (M): If I were the only one living in this world, I would have only one idea. But for some people you have to change that idea. I am not pleased with it but you are obligated. For example, if I am going to buy a car with my father, I choose one and my father chooses another. I insist on my choice. I try to disparage his choice. If I cannot success then there is nothing to do. Well, if I know what the subject is, I will answer better. On the topic of politics I hear out. But if I see a difference, if it's really true, I focus on the subject and I really remain constant. The opposite person tells and tells and I try to find mistakes. I weigh 
whether there is a contradiction in his sayings. I try to change his mind if I really value him. I listen to the opposite person and give the nod, I do not mind.

TC2 (F): Of course, decisions change. They change according to where I live, what I learn about the situation. I don't know, I mean, it doesn't matter. Sometimes it can change after very long time; sometimes it changes in the morning after the evening. Probably; if you are interacting with the right people in the place you live, of course it may change, but such a topic does not come to my mind. For one thing, if he is yelling too much while talking, I probably will not tell him my idea; he will not understand no matter what I do. If she does quite calm and coherent explanations, I will reveal my own ideas.

We asked the Turkish teacher candidates about their thoughts on social norms, advertising and propaganda, and how these affect them. One teacher candidate (TC5, F) stated that advertising and propaganda affects herself and one teacher candidate (TC2, F) expressed that she is partially influenced; while the other three teacher candidates stated that they were not affected. Social norms have been identified as a criterion that guides decisions for all participants. Examples from participants' statements are as follows:

TC1 (F): The social rules are not so. It must already have effect on people. For example, when I came from Mardin, the first, speeches affected me. I have not seen much tradition but the dishes are different. But when I'm going to do something, there is no such thing in my mind as I am doing something shameful. But it should actually, because people in the community can find odd. But the person must be himself, so I do not consider it. Maybe something negative, but I do not. My friends are so too. Some of them are very influenced by the rules an daven they warn me by saying "you are doing this in there, actually you shouldn't"

In the 2016-2017 academic year, the questions about the process of decision making and justification of their decisions were asked again to Turkish teacher candidates. When the responses were examined, remarkable findings were obtained. In particular, two teacher candidates responded to different questions through examples given in first grade interviews. A teacher candidate, in part, made the same explanation. While the participants state that they can change their minds by the guidance of the people they trust their sayings and knowledge, official and credible sources are enough for them to believe and persuade. A teacher candidate TC2 (F) has referred to the criterion of change in thought as usefulness and experience by saying "if I lived something to change it or if it is no longer important to me I change my idea". Again the basic data sources of teacher candidates are friends and the internet. A teacher candidate stated that he insists on not to change his thoughts. Examples of teacher candidates' statements are given below.

TC4 (M): If someone who is more knowledgeable than me tells me that my opinion is wrong, and if s/he explains it reasonably, then I change. But normally my thoughts do not change easily. If it is not reasonable news, it cannot change. If I have a very qualified opinion, it will not be affected. But if the effect of opinion is a little, then it may change. I changed the minds of others... it is relevant to my trust in the source of the news. For example, if an instructor I trust in says something, I do not try to get to the source much. After all, he's proven himself. But sometimes doctored news comes out on internet pages. I investigate the truth of this. I go into researching what I hear when it's a person or page that does not prove itself. When I am researching, if I have friends in the setting I am in, I first wonder about their views on that subject. I do research on that matter. After that I do this research on the internet. My internet page has four news pages. Whenever there is an incident, the report comes out from all. I base my idea on their common writings. Then, look at it on internet.

The opinions of Turkish teacher candidates about advertising and propaganda, social norms and how these affect them are also in parallel with the opinions they have in first class. Four teacher candidates stated that they were not affected by them. Social norms have been identified as a criterion that guides decisions for all participants. A teacher candidate (TC5, F) has shown her contradiction in terms by saying "social pressures generally do not impress me very much, but religion and style of clothing influence me". All the questions under the heading "Seeking evidence" were also directed to primary school mathematics teacher candidates. Teacher candidates are asked in which situations they believe the truth or validity of an idea, in which situations they changed their decisions and how they evaluate advertising and propaganda. The responses are presented under the themes of criterion of accuracy, criterion of decision-changing, effect of advertising and propaganda. When the opinions regarding the criterions of the accuracy of knowledge are examined; primary school mathematics teacher candidates were found deciding with emotional references. Teacher candidates believe in accuracy of knowledge according to the plausibility of the discourse or the state of being persuaded. In dual conversations, source of knowledge or the speaker's credibility seems to be enough to believe and persuade. Family elders, person's style and attitude, people's general perception / circle and age are the most basic criteria affecting the decisions of teacher candidates. Two teacher candidates summarized their thoughts on the subject as:

TC6 (F): I think it's true if what I see in the newspaper or what I hear from my friend sounds logical to me. If I think so too, I believe it and it sounds me logical. But if I do not like it, and it is against to my thought, I do not accept saying "no." I do not think it can be, it is absolutely lie. If I like it, it's okay. 
The primary sources of primary mathematics teacher candidates to "research" are the internet and close / trusting friends. On the other hand, expression of a participant (TC8, F) "But if I see with my eye, I hear with my ear, or I have concrete examples that are tangible, I believe it easier" is open to debate in the context of critical thinking skills. Primary mathematics teacher candidates were asked whether it is possible to change their decisions. While all of them declared that their decisions changed and they thought it was natural, a teacher candidate (TC9, M) explained the situation as:

TC9 (M): Of course, if I think I'm doing wrong, I change my mind. Sometimes things can happen like; you can see that what you really think is right is wrong. It can be after a long time. For example, as I am a mathematician, I give an example from Mathematics. For example, you know a formula and you can solve all the questions that come up against with it. In fact, you cannot solve all the questions with one formula. The lecturer says, you do not believe. That had happened to me; I invented a formula and I solved all the questions using it. Then the lecturer said that you cannot apply this formula to every question. I did not believe. Then he gave me a question and I saw that the formula did not really work. I agreed.

Three teacher candidates indicated that their families and close circles were very influential while changing their decisions. It was asked to the candidates of primary school mathematics teachers, their thoughts about advertisements and propagandas, social norms and how these affected them. Three teacher candidates (TC6, F; TC9, M; TC10, M) stated that the advertisement and propaganda did not affect themselves, while the three teacher candidates (TC7, M; TC8, F; TC11, F)stated that they were partially influenced. Social norms are important criteria that guide decisions for all participants. Examples of participants' statements are as follows:

TC7 (M): The subject that the advertisement refers to must be something I'm interested in. I do not think I like someting in the ad and buy it. Absolutely I go and look at it. Propaganda works, I think, affects people. I did not witness personally. For example, hand kissing. I attribute it to respect, I do not regard it as tradition. Social rules must go on. When I was in 9th grade, the students were making up. We firstly got annoyed. But we did the same in the 10th grade.

In the 2016-2017 academic year, when the questions about the decision making and justification of their decisions were asked again to primary school mathematics teacher candidates, remarkable findings were obtained. Especially two teacher candidates have mentioned that they think what the majority says important in describing a matter as correct. The most basic criterion used to believe in the correctness of knowledge is again family. A teacher candidate expressed her opinions by saying "First I look at the reliability of the source where from I hear it. Then look at on which subject it is told, where and when it is told." The opinions of primary school mathematics teacher candidates regarding the source of information are similar to their views in 2014. The main sources for participants to "research" are internet and close / trusted friends in 2017 too. The situation in which teacher candidates expressed "I read or research" was again observed as "reading from the internet" in 2017.

TC7 (M): But if it's a curious matter, first ask my friends, and if they do not know, I do search on different websites.

Unlike in 2014, in the fourth grade, changes in the situation of changing thinking of primary school mathematics teacher candidates were observed. In 2014, all the teacher candidates were open to change their minds, and in 2017, two teacher candidates (TC6, F; TC10, M) stated that they did not change their minds. A teacher candidate's thoughts are exactly the same as the first-grade thoughts.

TC6 (F): Sometimes I do not believe that it is wrong no matter how wrong it is. But even if I believe, it is very few. The thoughts of others are very valuable, but for me it is only an alternative thought.

The thoughts of primary school mathematics teacher candidates about advertising and propaganda, social norms and how these affect them differ slightly from the first grade. In the first grade, advertising and propaganda partially affected the three teacher candidates; in the fourth grade, no teacher candidate is influenced. In addition, while social norms were influential on all prospective teachers in first grade; in the fourth grade, two teacher candidates stated that social norms did not affect themselves. No, it can't

TC10 (M): I'm never impressed by something I do not like or do not care about. Social pressures...

\subsection{Teacher candidates' views on objectivity in first and fourth grades}

Teacher candidates were asked about their views on taking sides and objectivity and were asked to explain these two situations based on their own experiences. The questions were first directed to Turkish teacher candidates and then to primary school mathematics teacher candidates. The most striking point of the discourses of the Turkish teacher candidates is that they do not regard the taking sides or the objectivity as "good" or "bad". For teacher candidates, the concept of taking sides includes the meanings of being connected to a thought or a common point, objectivity includes the meanings of neutrality, not participating 
in both thoughts, reaching a common result. Only a teacher candidate has stated that he disapprove of taking sides. Examples of teacher candidates' expressions are given below.

TC5 (F): Taking sides is to be behind that person in an incident. Objectivity is not telling to anything to both sides, that's it. People do not have to take sides or be objective. It may vary depending on the setting. For example, I am seen as objective on political issues. I have my own opinion but I try not to reflect it to the other side. It's same in religious matters. I have a belief in my own way, but others do not need to know about it. There is something I take side and I really believe in. I stand behind it.

During the interviews, the question was asked to the Turkish teacher candidates, " How do you react it, if someone you love very much do something you get very angry with when someone else do it? " While four of the respondents said that in such a case, the person he loves will be more tolerant and personal closeness will soften his reaction; one (TC3, M) indicated that the reaction will not change regardless of who the other person is by saying "I will certainly open my mind to her, I will tell her not to do it again. It does not matter if it's my friend."

Turkish teacher candidates were asked again in 2017 about their views on taking sides and objectivity and were asked to explain these two situations based on their own experiences. Unlike the previous expressions, in the fourth grade, the three teacher candidates defined taking sides as a negative situation. A teacher candidate's explanation related to the topic is quite striking: TC1 (F): Taking sides means to be in one side and in one opinion. I define objectivity as a person who is not blindly bound up with anything and knows how to think critically. Taking sides is tightly bounding up with a certain ideology. Objectivity respects that ideology as well as other ideologies. I think the difference between them is respectdisrespect. A teacher candidate, on the other hand, describes the negative thoughts of taking sides as: TC3 (M): the word "party (taking side)" should not be in a language. Taking sides is according to whom, according to what? A person should not be a member of any community. If s/he becomes a member, s/he will proceed according to the upper mind's thoughts, so this word evokes a bad meaning for me. It's being in equal distance to all instutions. This is my ideology. Objectivity is not being a member of anything. When you take sides, you join a group. Objectivity is also a bridge to freedom. I think, everyone should use his/her own mind. S/he should not be under the influence of anybody. S/he must act rationally first.

In the fourth grade, the question was asked to the Turkish teacher candidates again: " How do you react it, if someone you love very much do something you get very angry with when someone else do it? ". Previously, two teacher candidates (TC5, F; TC1, F) who stated that the reaction to their loved ones would be softening this time stated that they would express their reaction harshly. Likewise, the teacher candidate (TC3, M), who stated that his reaction cannot be changed according to the person before, expressed that his reaction to his loved ones would be softer this time.

After the Turkish teacher candidates, all the questions regarding taking sides and objectivity were directed to the primary school mathematics teacher candidates; they are required to explain these two situations according to their experiences. Primary school mathematics teacher candidates have expressed the concepts of taking sides and objectivity differently. A teacher candidate (TC6, F) indicated that taking sides is more correct by saying "... taking sides is not exactly the same as the fanatic, but similar. Objectivity is against them. But objectivity is not good. I think that people's thoughts do not thrive so. One can not develop himself. Of course, it's not good being too much fanatic, but people will not be objective either "while another teacher candidate (TC9, M) defends objectivity by saying "... objectivity is generally better. Nobody comes to discuss with you when you are objective. When you take a side, you have to constantly argue ... They're all discussing each other. There are even dead people". The other four teacher candidates did not consider taking sides or the objectivity as "good" or "bad". They mentioned that if there is a matter of interest, closeness or a situation that affects human life negatively, they should take sides and they can take side or be objective according to their life situation. Examples of teacher candidates' statements are given below.

TC8 (F): These are the partisanship that emerges because of our religion and national feelings. But human beings must take the sides that do not contradict their value judgments, or in situations that move their national feelings into action. But if there is no crime against humanity or a situation that kills or exploits people in the country which we have no political or social relations, it is necessary to leave its internal affairs to itself. Animals cannot be slaughtered too. They are already weak creatures, compared to humans. Anyway a person and an animal cannot be considered equal; that is, in all situations which is considered as crime against humanity, one definitely must take a side. But it will not be considered a crime against humanity, how to say, I do not remember an example. There is a protest in a country, Turkey can be take side if there is a protest related to human rights, but it is not necessary for Turkey to take side for something ordinary. Both people and countries can take sides from time to time. There is no good or bad in the situation of taking sides or objectivity. According to one's own values and point of view this may change. I think it would be wrong to say that it is good or it is bad. TC11 (M): Taking side is not a bad thing. (Two friends are arguing.) I do not 
take a side. If one is wrong, I tell it, I do not support. I take side so. In such cases, I cannot distinguish either taking sides or objectivity. One must be objective in war situations. If others are making war, it should not be supported. One need to take side of right and should also say "stop". I begin the sentence objectively and end it by taking side. During the interviews, question "How do you react it, if someone you love very much do something you get very angry with when someone else do it?" was asked to primary school mathematics teacher candidates. The two male teacher candidates (TC7, TC11) who participated in the survey said that in such a case they would tolerate the loved ones and their personal intimacy would soften their reactions, they told that they cannot have a heart to say or do something. A teacher candidate (TC8, F) stated that her reaction will not change, she will not favor him and only her appeal would be more moderate by saying "... I speak more formal with other people. I tell, but in a moderate way to acquaintance ones. You are closer to the people you know, and you do not want to hurt them. So maybe it is not because I want to hurt other people, but because we do not have any sincerity in advance. Not favor." Three teacher candidates (TC6, F; TC9, M; TC10, M) say that if the person is acquaintance, they would get angrier.

In 2017, the primary school mathematics teacher candidates' opinions were asked again about taking sides and objectivity. Unlike their previous statements, when it came to the fourth grade, all teacher candidates had no good or bad evaluation of taking sides and objectivity and it has been observed that the ideas of the two above- mentioned teacher candidates (TC6, F; TC9, M) have changed. Teacher candidates have defined the taking sides as sympathizing with a topic, being side with something, being in favor of an opinion / situation. Objectivity is defined as being in non-side, not being involved in anything, being neutrality, non-thinking community. A teacher candidate's description related to the topic is quite striking:TC8 (F): taking sides is one's being in the side that s/he finds closer to his/her ideas, interest, etc. and objectivity is sort of being mixed up in an affair. If I exemplify this with mathematics, to be able to take a side one should be in the intersection set with the person or community that s/he takes side. If people do not intersect in one or more other subjects, there is no side relationship. This intersection can be pure and profitless, but also it can be in the direction of interests. In fact, the best example of this is the alliance countries in a war. While countries that are trying to achieve the same goal are gathered on the same side, the opposing ones also gather against and form a counter side. In case of objectivity, one is neutral and treats equally to all kinds of opinions. There is no certain opinion or ideology in objectivity.

During the interviews, the question was asked to the primary school mathematics teacher candidates, " How do you react it, if someone you love very much do something you get very angry with when someone else do it? " Teacher candidates' views on this topic differed from the previous ones. While the three teacher candidates' (TC6, F; TC8, F; TC11, M) thoughts did not change in the fourth grade, a teacher candidate (TC7, M) who stated previously that his reaction to the loved one would be softer said that he would express his reaction harshly this time. Two teacher candidates (TC9, M; TC10, M), who stated that their reaction to the loved ones would be tougher, said that the reaction would be softer this time. Primary school mathematics teacher candidates were asked in 2017 again, "If they should dismiss someone from employment as a boss, who will they dismiss and how they will determine this person". Teacher candidates stated that when they decide on the people to be dismissed from the work, they will act rationally by not using emotional criteria and the only criteria will be the job performance. A teacher candidate said that he could not do such a thing. Finally, as a continuation of the above question, "What would be your attitude if the person whom you decided to dismiss is close to someone who you cannot offend?" was asked to primary school mathematics a teacher candidate. Two teacher candidates (TC8, F; TC9, M) stated that they would change the person to be dismissed from the job, or they might consider a different possibility.

With this research, it was aimed to determine the thoughts of the prospective teachers about their critical thinking skills by referring to their own opinions and to examine whether these ideas are influenced by the period of undergraduate education. Within the scope of the research, the interviews were conducted with the teacher candidates in the first year and last year of the undergraduate education and the findings of both interviews were approached comparatively. Questions directed to teacher candidates are sample cases that are compiled from daily life practices and field independent. They are asked to explain, with the reasons, how will be their feelings, thoughts, and reactions to them. When the research findings were examined, it is seen that the opinions of the teacher candidates about critical thinking generally did not change much from the first year to the fourth year. The point of view that they have while starting their undergraduate education remain the same in the course of the time. Teacher candidates who can be described as "critical thinkers" in the direction of their answers complete their education in the way they started; it is seen that the teacher candidates who are thought to be far away -according to their answers- from this thought are also assigned/will be assigned to the "teaching" profession by completing their undergraduate education with the same thought. When dealt with in this context, undergraduate education and informal aspects of this education should be considered. What is and what should be the social, cultural and educational contribution of the four-year undergraduate education to the teacher candidate are among the topics to be discussed. 
Interviews were made with students of Turkish and primary school mathematics teachers' undergraduate program. The Turkish teacher education program differs from the primary mathematics teacher education program in terms of course content and type of LYS (university admission exam) score used for student admission, but the responses of teacher candidates to examples from daily life are similar. On the other hand, the courses taken during the undergraduate education process and course contents also differ for both departments. The inability to observe the effect / contribution of all these differences on the thought systems reveals the shortcomings in the context of the transferability of course content in education.

Teacher candidate discourses are examined in terms of "self-recognition", "decision making", generating alternative", "seeking evidence" and "objectivity". Looking at the theme of "self-recognition ", it is seen that all participants regardless of their branch can identify themselves confidently and easily in both the first and fourth grade. While benefiting from environmental references from time to time, it is important for teacher candidates to be able to articulate their positive and negative aspects. According to Cüceloğlu [8], a self-aware person is aware of the events in the external world as well as his own internal experiences. As he can observe the effects of the circle on himself, he knows that he is also active in the process. Being in the roles of learning environment regulators and class administrators in the educational environment in the near future teacher candidates' being aware of their own competencies and limitations gain importance in the context of the role of "environmental regulator".

Under the theme of "decision making", teacher candidates were asked how they decided, how they gathered information, how they thought and acted in case of wrong decision. Under this heading, when the changes in thoughts from first-grade to fourth-grade are examined, the change in the thoughts of Turkish teacher candidates is higher than that of primary school mathematics teacher candidates. Especially in the first grade teacher candidates who emphasized that they could make "instant" decisions, ignoring the importance of the subject, emphasized that they would make a "profit and loss account" when they reached the fourth grade. There can be many factors that explain this change. Age is one of these. Experience that comes with age may have influenced the decision making mechanisms of teacher candidates. There are many research findings that show that age has an influence on individuals' ability to think critically [33-36]. Gilstrap and Dupree [37] deal with the situation in a different context and emphasized that the increase in the time students spend in school has a positive influence on critical thinking. When asked to teacher candidates how they gather information, it is seen that the primary source of information for all teacher candidates is the family. When considered in the context of its effect on critical thinking skills, this finding is in line with many of the literature on the subject [38-44]. When they were asked what their feelings and thoughts were after the wrong decision, they responded in the first grade with the concepts of regret and sadness, while in the fourth grade this situation was expressed as "stand behind their decision". However, standing behind the wrong desision is not an expected behavior for critically thinking individuals. According to Kazanc1 [14], seeing and struggling to correct mistakes is a sign of thinking skill and among the qualifications that a scientist should possess.

The theme of "generating alternatives" is again one of the titles that teacher candidates' thoughts differentiate according to the branches. Opinions and thoughts of the Turkish teacher candidates regarding the topic differed from the first grade to the fourth grade. However, this differentation is not favorable or desirable. Some teacher candidates who find the alternative "confusing" in the first grade see it as necessary in the fourth grade, while for other teacher candidates this situation have progressed in the opposite direction. Teacher candidates do not have standard thinking about openness to change and belief to the need for searching alternative. In primary school mathematics teacher candidates, generally, from the first grade to the fourth grade, the point of view which is unchanging and being content with what they have is dominant. Alternative generating is a common definition used among critical thinking definitions [15, 45, 46]. Openness to alternatives and new experiences are indicatives of the need for thinking. One of the most striking findings of the research is the findings obtained under the title "seeking evidence". In the research process, it was observed that the candidates' readings were "read from the internet" and when they expressed "research" they mean "establishing a communication chain with their friends via social media or sms". The situation is similar for both branches. It is thought-provoking that the teacher candidates who are expected to develop their students' basic skills, such as scientific thinking skills and critical thinking skills take different track other than scientific research. The regulation by the Ministry of National Education in 2004 critical thinking skills defined as an ability to look at matters with a questioning approach based on suspicion, comment on, and make decisions. It also has sub-dimensions such as finding cause-and-effect relationships, capturing similarities and differences in detail, sorting by using various criteria, determining the reasonableness and validity of given information, analyzing, evaluating, sense-making, and making inferences [47-49]. The skill is presented to the students in an explicit way through the teaching programs, implicitly with the teacher's attitudes and behaviors. In this context, the attitudes, perceptions and competences of the teacher candidates regarding critical thinking are important. 
The point of view of teacher candidates towards social norms is also covered within the scope of the research. In general, all participants argued that they were affected by this situation and that this was a normal behavior. In terms of advertising and propaganda, thoughts vary. While some teacher candidates have indicated that they will be affected by this situation, some see themselves far away from this situation. Some argues that their thoughts will not change with the influence of others. Both situations are thought-provoking in the name of critical thinking. Because critical thinking is defined as questioning reasons before believing in or doing something, and making decisions after a deep thought process [45]. Critical thinking, on the other hand, is also the basis of democratic citizenship. A democratic citizen is defined as a person who can think freely and aloud when necessary, who can can make decisions on his own by taking into consideration the thoughts of others, who can look at events from different angles by not being under any influence and who does not accept the various propaganda and advertisements blindly and without questioning [14]. The expectation from the teacher candidates is to internalize the democratic citizenship characteristics and to be role models within the classroom. Teacher candidates' "objectivity" perceptions emerged as the closest title to critical thinking. The teacher candidates in both branches treat the concepts of taking sides and objectivity in a similar and correct way and regard it as a "normal" situation. However, when the objectivity of teacher candidates is elaborated through different inquiries, it is observed that attitudes and behaviors may change in situations such as "acquaintances, respected ones, loved ones". Being objective in interaction with students in the classroom, being neutral and equally distant to the events is one of the important skills for the teacher. For this reason, "do not have a hearth for the loved ones" or "ignore because not to offend" are not acceptable. Within the classroom in which the teacher is a role model, the teacher has duties and responsibilities such as questioning, decision making based on evidences, and employment of democratic processes. In the pre-service period, awareness of these duties and responsibilities must be acquired. However, the fact that the not changing status of the teacher candidates who have reached the end of the education period has to be re-examined within the framework of education faculty programs and teacher competencies.

\section{CONCLUSION}

As a result, the critical thinking perceptions of Turkish and primary mathematics teacher candidates and their practices in daily life are similar but not "adequate". The extent to which they will contribute to their students in a situation where they are not adequately qualified is among the issues that need to be emphasized.

In addition, research findings open the debate on the transferability of critical thinking skills which is included/needed to include in the education faculty curricula to the life. In the curriculum, it is suggested to add critical thinking skills through activities to be held in either elective courses or compulsory courses. Research can be repeated with the participation of prospective teachers and interviews can be deepened.

\section{REFERENCES}

[1] C. Aslan, "Düşünme becerilerini geliştirici dil ve edebiyat öğretimi ortamları -bir eğitim durumu örneği-," Balıkesir Üniversitesi Sosyal Bilimler Enstitüsü Dergisi, vol. 13(24), pp. 127-152, 2010.

[2] C. Aslan, "Soru sorma becerilerini geliştirmeye dönük öğretim uygulamalarının öğretmen adaylarının soru sorma becerilerine etkisi," Ĕgitim ve Bilim, vol. 36(160), pp. 237-249, 2011.

[3] S. Sever, "Öğretim dili olarak Türkçenin sorunları ve öğretme öğrenme sürecindeki etkili yaklaşımlar," Eğitim Bilimleri Fakültesi Dergisi, vol. 34(1-2), pp. 11-22, 2002.

[4] O. Öztürk, Sorma-bilme dürtüsü ve girişim dürtüsü nasıl yok ediliyor?, Ankara: TÜBA Akademi Forumu 11, 2004.

[5] Türk Dil Kurumu, "Büyük Türkçe Sözlük," Available online at: www.tdk.gov.tr, Sep 2016.

[6] Y. Özden, Öğrenme ve ögretme, Ankara: Pegem Yayıncılık, 1998.

[7] M. Lipman, Thinking in education, Cambridge: Cambridge University Press, 1994.

[8] D. Cüceloğlu, İyi düşün doğru karar ver, İstanbul: Sistem Yayıncılık, 1995.

[9] C. Aslan, "Türkçe ders kitaplarındaki metin sonu sorularının incelenmesi," In Proceeding of the XVI. Ulusal Eğitim Bilimleri Kongresi, Gaziosmanpaşa Üniversitesi, Tokat, 2007.

[10] F. Güneş, Türkçe öğretimi ve zihinsel yapılandırma, Ankara: Nobel Yayın Dağıtım, 2007.

[11] N. Karasakaloğlu, A. S. Saracaloğlu, and S. Yılmaz Özelçi, "Türkçe öğretmeni adaylarının okuma stratejileri, eleştirel düşünme tutumları ve üst bilişsel yeterlilikleri," Ahi Evran Üniversitesi Kırşehir Eğitim Fakültesi Dergisi (KEFAD), vol. 13(1), pp. 207-221, 2012.

[12] B. Hudgins and S. Edelman, "Teaching critical thinking skills to fourth and fifth graders through teacher-led small group discussions.," Journal Of Educational Research. vol. 79(6), pp. 333-342, 1986.

[13] R. J. Sternberg, Handbook of creativity, New York: Cambridge University Press, 1999.

[14] O. Kazanc1, Eğitimde eleştirici düşünme ve ögrretimi, İstanbul: Kazancı Kitap AŞ, 1989.

[15] P. A. Facione, Critical thinking: What it is and what it count, California: California Academic Press, 1998. 
[16] T. Üstündağ, Yaratıcıllğa yolculuk, Ankara: Pegema Yayıncılık, 2003.

[17] O. Akınoğlu, "Eleştirel düşünme becerilerini temel alan fen bilgisi öğretiminin öğrenme ürünlerine etkisi," $P h D$ Thesis, Hacettepe University Educational Science Institute, Ankara, 2001.

[18] G. Gojkov, A. Stojanović, and A. G. Rajić, "Critical thinking of students- indicator of quality in higher education," Procedia-Social and Behavioral Sciences. vol. 191, pp. 591-596, 2015.

[19] F. Munzur, "Türk dili ve edebiyatı ders kitaplarında eleştirel düşünme eğitimi üzerine bir değerlendirme (Edebiyat 1 ve 2 Örnekleri)," PhD Thesis, Ankara University Social Science Institute, Ankara, 1999.

[20] S. Rezaei, M. Bagherkazemi and A. Derakhshan, "Critical thinking in language education," Journal of Language Teaching and Research, vol. 2(4), pp. 769-777. 2011.

[21] S. Sinprakob and N. Songkram, "A proposed model of problem-based learning on social media in cooperation with searching technique to enhance critical thinking of undergraduate students," Procedia-Social and Behavioral Sciences. vol. 174, pp. 2027-2030, 2015.

[22] G. Thomas and G. Smoot, "Critical thinking: A vital work skill," Trust for Educational Leadership, vol. 23, pp. 3438, 1994

[23] W. Huitt, "Critical thinking: An overview," Educational Psychology Interactive, 1998. Retrieved March, 2009, from http://chiron.valdostaedu/whuitt/col/cogsys/critthnk.html. [Revision of paper presented at the Critical Thinking Conference sponsored by Gordon College, Barnesville, GA, March, 1993.]

[24] H. Bağcı, and N. K. Şahbaz, "Türkçe öğretmeni adaylarının eleştirel düşünme becerileri üzerine bir değerlendirme," Mersin Üniversitesi Ë̆itim Fakültesi Dergisi, vol. 8(1), pp. 1-12. 2012.

[25] A. Çiçek Sağlam and E. Büyükuysal, "Eğitim fakültesi son sınıf öğrencilerinin eleştirel düşünme düzeyleri ve buna yönelik engellere ilişkin görüşleri," International Journal of Human Sciences, vol. 10(1), pp. 258-278. 2013.

[26] S. A. DeWaelsche, "Critical thinking, questioning and student engagement in Korean university English courses," Linguistics and Education, vol. 32(2015), pp. 131-147, 2015.

[27] E. V. Fella and N. A. Lukianovaa, "British universities: İnternational students' alleged lack of critical thinking," Procedia - Social and Behavioral Sciences, vol. 215, pp. 2-8, 2015.

[28] L. Niu, L. S. Behar-Horenstein and C. W. Garvan, "Do instructional interventions influence college students' critical thinking skills? A meta-analysis," Educational Research Review, vol. 9, pp. 114-128. 2013.

[29] E. C. Danvers, "Criticality's affective entanglements: rethinking emotion and critical thinking in higher education," Gender and Education, vol. 28(2), pp. 282-297, 2016.

[30] C. Kavcar, "Cumhuriyet döneminde dal öğretmeni yetiştirme," Ankara Üniversitesi Eğitim Bilimleri Fakültesi Dergisi, vol. 35(1-2), pp. 1-14, 2002.

[31] T. Özsevgeç and E. Altun, "Fen ve teknoloji öğretmenlerinin eleştirel düşünme becerisine yönelik görüşleri," In Proceeding X. Ulusal Fen Bilimleri ve Matematik Ĕgitimi Kongresi, Niğde, 27-30 Jun 2012.

[32] S. Yılmaz Özelçi, "Eleştirel düşünme tutumuna etki eden faktörler: Sınıf öğretmeni adayları üzerine bir çalışma," PhD Thesis, Adnan Menderes University Social Sciences Institute, Aydın, 2012.

[33] K. L. Y. Ku and I. T. Ho, "Dispositional factors predicting Chinese students' thinking performance," Personality and Individual Differences, vol. 48(201), pp. 54-58, 2010.

[34] Ş. Ay and H. Akgöl, "Eleştirel düşünme gücü ile cinsiyet, yaş ve sınıf düzeyi," Kuramsal Eğitimbilim, vol. 1(2), pp. 65-75, 2008.

[35] D. Kürüm, "Öğretmen adaylarının eleştirel düşünme gücü," Master Thesis, Anadolu University Social Sciences Institute, Eskişehir, 2002.

[36] P. A. Facione, N. C. Facione and C. A. F. Giancarlo, The Motivation to Thinking in Working and Learning, Preparing Competent College Graduates: Setting New and Higher Expectations for Student Learning, San Francisco: CA Jossey-Bass Publishers, pp. 67-79, 2000.

[37] D. L. Gilstrap and J. Dupree, "A regression model of predictor variables on critical reflection in the classroom: integration of the critical incident questionnaire and the framework for reflective thinking," The Journal of Academic Librarianship, vol. 34(6), pp. 469-481, 2008.

[38] S. Tümkaya, M. Çelik and B. Aybek, "Lise öğrencilerinde boyun eğici davranışlar, otomatik düşünceler, umutsuzluk ve yaşam doyumunun incelenmesi," Çukurova Üniversitesi Sosyal Bilimler Enstitüsü Dergisi, vol. 20(2), pp. 77-94. 2011.

[39] S. Tümkaya and B. Aybek, "Üniversite öğrencilerinin eleştirel düşünme eğilimlerinin sosyo-demografik özellikler açısından incelenmesi," Çukurova Üniversitesi, Sosyal Bilimler Enstitüsü Dergisi, vol. 17(2), pp. 387-402, 2008.

[40] B. Palut, "Düşünme stilleri ve anne-baba tutumları arasındaki ilişki," Dokuz Eylül Üniversitesi Buca Ĕ̌itim Fakültesi Dergisi, vol. 24, pp. 01-11, 2008.

[41] R. Arı and Z. Ş. Seçer, "Farklı ana baba tutumlarının çocuklarin psikososyal temelli problem çözme becerilerine etkisinin incelenmesi," Selçuk Üniversitesi Sosyal Bilimler Enstitüsü Dergisi, vol. 10, pp. 451-464, 2003.

[42] Ö. Keleşoğlu, "Bireylerin ana-baba tutumlari ile duygusal zeka düzeyleri arasindaki ilişkiler," Master Thesis, Atatürk University Social Sciences Institute, Erzurum, 2008.

[43] M. Özel, "Ergenlerin denetim odaklarına ve algıladıkları ebeveyn çocuk yetiştirme tutumuna göre karar verme biçimlerinin incelenmesi: Darıca ilçesi örneği," Master Thesis, Maltepe University Social Sciences Institute, İstanbul, 2009.

[44] I, Üredi and M. Erden, "Öz-düzenleme stratejileri ve motivasyonel inançların yordayıcısı olarak algılanan annebaba tutumları," Türk Eğitim Bilimleri Dergisi, vol. 7(4), pp. 781-811, 2009.

[45] R. H. Ennis, Goals for critical thinking curriculum, Belmont: Wadsworth Publishing Company, 1985. 
[46] R. W. Paul and L. Elder, "Critical thinking: strategies for improving student learning," Journal of Developmental Education, vol. 32(1), 2008.

[47] Milli Eğitim Bakanlı̆̆1, Tebliğler Dergisi, vol. 67(2563), pp. 734, 2004.

[48] Milli Eğitim Bakanlı̆̆ı Öğretmen Yetiştirme ve Eğitimi Genel Müdürlüğü, Öğretmen yeterlikleri: ögretmenlik mesleği genel ve özel alan yeterlikleri, Available online at: http://otmg.meb.gov.tr/YetOzel.html, 2008.

[49] Türk Eğitim Derneği, Öğretmen yeterlikleri. Ankara: Adım Okan Matbaacılık Basım Yayın Tanıtım Organizasyon Ticaret Limited Şirketi, 2009.

\section{BIOGRAPHIES OF AUTHORS}

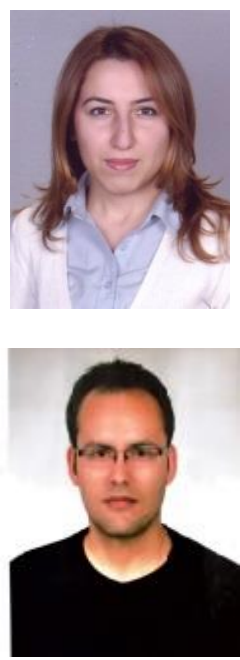

Serap Yılmaz Özelçi is an assistant professor in the Department of Educational Sciences, Ereğli Faculty of Education, in Necmettin Erbakan University. Her professions are tecaher training, critical thinking and teaching critical thinking.

Gürbüz Çalişkan is a $\mathrm{PhD}$ candidate in the Department of Turkish Language Education at Ankara University (Turkey). He works as a research assistant at Necmettin Erbakan University (Turkey). His researches focus on Turkish Language Education, teaching Turkish as a foreign language and children's literature. 